\title{
Dreams Interpretation of The Main Character in A Monster Calls Movie Directed By J.A. Bayona
}

\author{
Unpris Yastanti ${ }^{1}$, Retno Ameliani ${ }^{2}$ \\ ${ }^{1,2}$ Sastra Inggris, Universitas Bina Sarana Informatika \\ Jl. Kramat Raya No.98 Senen Jakarta Pusat 10450 \\ Correspondence email: unpris.uys@bsi.ac.id
}

\begin{abstract}
Abstrak. Tujuan dari analisis ini adalah untuk mengetahui interpretasi mimpi dari karakter utama yang bernama Conor O’Malley dalam film A Monster Calls yang disutradarai oleh J.A. Bayona. Metode analisis ini adalah metode deskriptif kualitatif. Teori yang penulis gunakan untuk menganalisis interpretasi mimpi berasal dari Sigmund Freud. Hasil dari penelitian ini adalah: 1.) Penafsiran mimpi dan tiga cerita dalam mimpi tokoh utama terkait dengan konflik yang dialami oleh tokoh utama, yang bernama Conor. 2.) Ada beberapa jenis mimpi dalam analisis ini dan jenis mimpi yang dialami Conor adalah mimpi buruk. Mimpi buruk Conor adalah reaksi terhadap penyakit yang diderita ibunya.
\end{abstract}

Kata kunci: interpretasi mimpi; karakter utama; film

\begin{abstract}
The purpose of this analysis is to identify dream interpretation of the main character, Conor O'Malley in A Monster Calls movie directed by J.A. Bayona. The method of this analysis is descriptive qualitative method. Sigmund Freud's theory is used to analyze. The results of this research show that: (1)The interpretation of dream and the three stories in dream of main character are related to conflict that experienced by Conor.(2) The type of dream experienced by Conor is nightmare. Conor's nightmare is a reaction to the illness suffered by his mother.
\end{abstract}

Keywords: Dream Interpretation; Main Character; Movie

\section{INTRODUCTION}

Literature is the result of human creation to express their life (Yastanti et al. 2018). Through literature, author can write conditions that occur around the community where they live (Khairunnas et al., 2018). Literature refers to works of the creative imagination, including poetry, drama, fiction, and non fiction. Literature is the result of the author in order to communicate to the reader or the audience, through literature the author can write conditions that occur around the community where they are (Klarer, 2004; Roberts \& Jacobs, 2006).

In literature, people can learn about movie. Movie is a media to exploring someone's idea. It could be a real story or a fiction story. Movie may contain inspiration, knowledge, and someone's experience. Movie was made to entertain those viewers, give them a moral message, and also motivation (Yastanti \& Widhiyanto, 2018; Arfani, 2018; Santas, 2002; Petrie \& Boggs, 2008).

In this era, watching movie becomes one of daily activities for some people. People may have different goals in watching movie, such as to add refreshing knowledge, learn a foreign language, know foreign culture, get some entertainment or do research. Many movies have elements of unconscious such as hallucination, fantasy, and dream.

Dream is an event which happens in someone when they are sleeping. In their dream, there are many events which appear during sleep, such as event in real life, experience, or impossible thing. In interpreting a dream, people need a time because there are many symbols in dream that must be understood. This theory tries to associate a dream to someone's life. Dreams can influence someone's behaviour, because conflict and stress cannot be finished in through daily life (conscious), they can appear in a dream (unconscious) (Bethards, 2003; Schweitzer, 2003; Schredl, 2018).

There are four types of dreams, they are:

(1) Daydream. Daydreaming is classified as a level of consciousness between sleep and wakefulness. Studies show that you have the tendency to daydream an average of 70-120 minutes a day;

(2) Lucid dream, is one of the most fascinating subjects for dreamers and dream researchers alike. In many cases realizing it is a dream immediately wakes the dreamer and ends the dream. In other word, inside the dream, people know they are dreaming and people can also control anything in it.

(3) Nightmare. It happen to the people who have suffered traumas, or been through very upsetting experiences or upheavals, often suffer from very vivid nightmares during which they relieve the traumatic experience.

(4) Epic dream. It is so huge so compelling and so vivid that you cannot ignore them. The details of such dreams remain with you for years as if you dreamt it last night. These dreams posses much beauty and contain many archetypal symbology. It feels like a life changing experience (Hale, 2010; Tejera, 2009; Domhoff, 2013). 


\section{METHOD}

The writers use descriptive qualitative method (Parse, 2001) to analyze dream interpretation of the main characters in A Monster Calls movie. The writers find and get some data, and then analyze the data and information by searching internet and library research. In this paper, the writers do some procedures. The writers decide to analyze the movie A Monster Calls as a research material. The writers prepare several theories to support the research. Then the writers watch the movie several times and started analyzing the scenes and conversations needed to be researched. After that, the writers analyze the data. In this section, the writers find the result of the statement of the problem.

\section{FINDING AND RESULT}

In this part the writers discuss the analysis and find the result of research question. Conor O'Malley is a gloomy teenager because of the cancer suffered by his mother. Conor also experienced nightmare about his mother. The nightmare can be seen through his dialogue and scene in the movie below:

\section{The Dream Interpretation in a Monster Calls Dream of his mother}

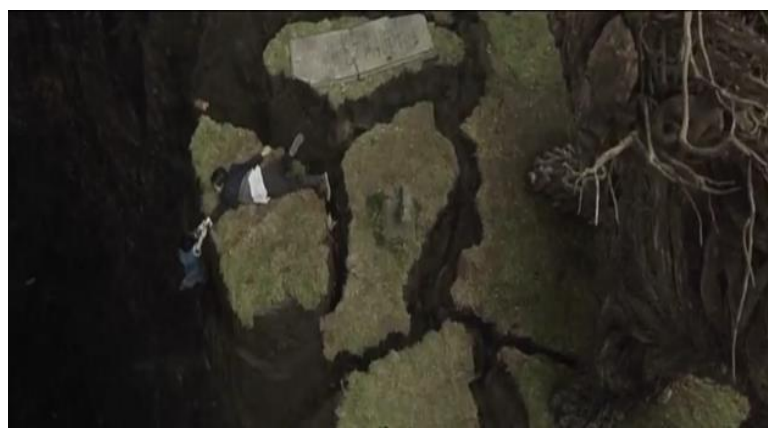

Picture 1. Mother fall into a big hole.

The story begins with Conor's nightmare. The cause of his nightmare was because the cancer suffered by his mother. In his dream, Conor could not help his mother who fell into a big hole in the funeral behind their house. When his mother fell, Conor always woke up from his dream. From the explanation above, dream interpretation can be used for interpreting everything hidden inside unconsciousness.

\section{Dream of first meeting with the Monster}

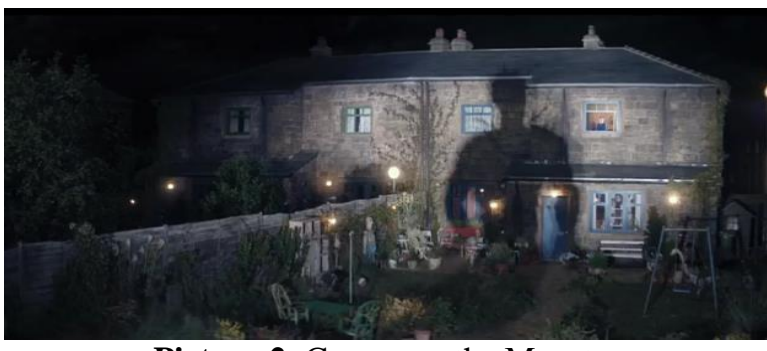

Picture 2. Conor see the Monster
Monster: "I have come to get you, Conor O'Malley. Why don't you run, Conor O'Malley? Why don't you run for your mother?"

Conor: "You leave her alone! I'm not afraid of you!" Monster: "I will visit you again on further nights, Conor O'Malley. And I will shake your walls until you wake. And then I will tell you three stories."

One night at exactly 12:07 a.m., when Conor was drawing a yew tree, a voice calls him from the window. When Conor opened the window, he saw a monster formed from a twisted mass of branches and leaves, a Yew tree. The monster is curious why Conor is not afraid of him. The monster tells Conor that he will tell him three true stories. After the stories, Conor must tell a true story of his own or the monster will eat him. In this section explains that Conor does not want to lose his mother because his mother is everything to Conor. Before Conor dream of meeting a tree monster, Conor watched King Kong movie with his mother. It means, Conor's dream of meeting the monster related to the situation when he watched the King Kong movie. King Kong is described as a strong figure and Conor needed a strong figure like King Kong to relieve his pain. Then, appeared in the form of a giant Yew tree monster, to help him relieve his pain.

\section{Three stories from the monster in the main character's dream}

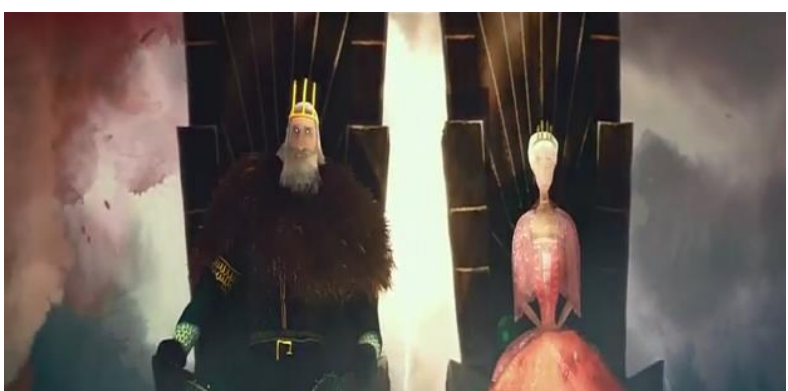

Picture 3. The story about a King, Queen, and Prince

Monster: "What took you so long? It is time for me to tell you the first tale."

Conor: "I don't need a tale. I need a bus ticket for my grandma. Or at least help me with my grandmother. But all you want to do is tell me stories."

Monster: "Stories of how I toppled my enemies. Stories of how I slew dragons. Let me tell you a tale of when I came walking. Let me tell you of the end of a wicked queen and how I made sure she was never seen again."

Conor: "Go on, then."

The story started with a peaceful kingdom, which is Conor's wish fulfillment to have a beautiful life and live it happily. Conor started to drew connections 
between the story and his own life. Conor identified himself as the prince, and queen defined as cancer suffered by his mother which made Conor lose all happiness. A connection can be made between Conor's situation and the monster's story showed of how Conor's unconscious wanted to kill his mother who is portrayed as his bride. He wants to end his mother suffering because by ending his mother suffering, it also ends her suffering. He is always thinking about losing his mom.

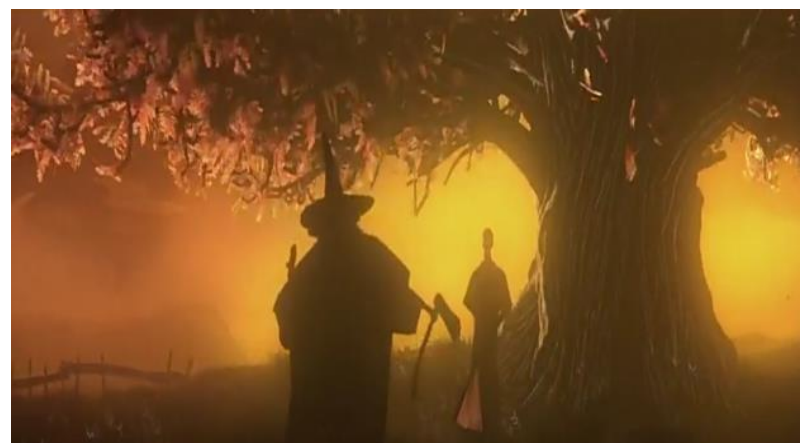

Picture 4. The story of The Apothecary and The Parson

Monster: "Now, I have come to tell you the second tale."

Conor: "Is this as bad as the last one?

Monster: "It ends with proper destruction, if that's what you mean. It's about a man who thought only of himself, who wasn't as generous as he should have been. A man who gets punished very badly indeed." Monster: "The apothecary wanted the yew tree very badly. But in order to harvest these things, he would have to cut it down. And this, the parson would not allow."

It showed that the Yew tree defined as Conor's mother treatment, which causes Conor believe that his mother will be able to be cured by it. Meanwhile, the parson is the other side of Conor. He wanted his mother to recover as before, but on the other side Conor wishes his mother was dead. It is just because he could not stand to see the pain of his mother.

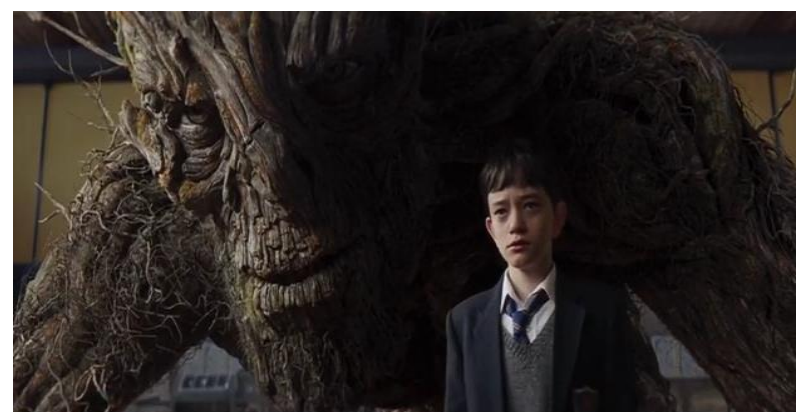

Picture 5. The story of An Invisible Man

Conor: "What took you so long?"

Monster: "It is time for the third tale. There was once an invisible man, who had grown tired of being unseen. It was not that he was actually invisible. It was just that people had become used to not seeing him. One day, the invisible man couldn't stand it anymore. He kept wondering: if no one sees you, are you really there at all?"

Conor: "What did the invisible man do?"

Monster: "He called for a monster."

The monster told third story about an invisible man. it is most directly related to Conor's life. Conor is an invisible man whom people have become used to not seeing. Harry's bullying is heartbreaking. All Conor will is to regain the connection and support from his peers that he has lost. Conor is so desperate to end his feeling of isolation that he resort to violence, even though he is normally a very gentle boy. Once again, Conor used the monster as an outlet for his anger and sadness. He believes that the monster is beating Harry up, but given the school cafetaria incident. It is implied that Conor is the monster, consumed by his grief and channeling his rage into violence.

\section{Types of Dream in A Monster Calls movie}

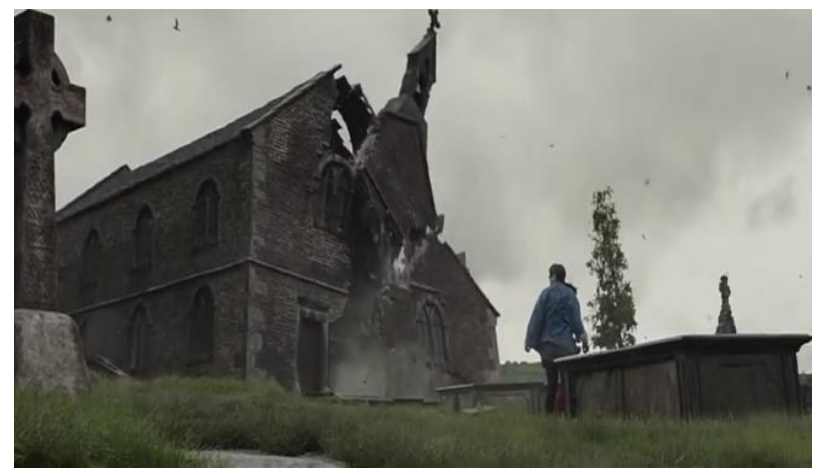

Picture 6. Conor's nightmare about his mother

Conor: "Mum! Mum! Mum!" Mother : "Conor!
Don't let me go!"
Conor: "I won't!
Mother: "Conor!" Conor : "Mum!
Monster: "Here is the truth of Conor O'Malley. Here
is your nightmare”"

From the dialogue in the scene above, Conor was at the place and suddenly his mother was about to fall into a large hole that appeared in the middle of the funeral. Conor could not save his mother, and he woke up. The dream, which is Conor's internal action proves that he has a sense of worry about his mother illness but also wants his mother die soon. So, the type of dream experienced by Conor was nightmare. Conor's nightmare was a reaction to the illness suffered by his mother. It can be interpreted as true hopes, but do not mean that the dreamer has a present wish for death of his parents. 


\section{CONCLUSIONS}

The dream interpretation of the main character, Conor, the dreams happen because the cancer suffered by his mother. Conor's dream meeting with the monster explain that Conor needed a strong figure like the monster to relieve his pain because of Conor not having anyone else to tell other than his mother. The meaning of three stories from the monster in Conor's dream. The first story is about of wish, love, and norm which is Conor's inner conflict. The second story is about two character (the apothecary and the parson) which is described the conflict that experienced by Conor. The third story is about an invisible man who has grown tired being unseen which is related to Conor's life.

The type of dream in this movie is nightmare. It happens in several times. Conor's nightmare about his mother. His fears of losing his mother are repressed because the cancer suffered by his mother. These fears reaction then appear in the form of nightmare about his mother and he got dream at night.

\section{REFERENCES}

Arfani, S. (2018). The Schizophrenia in The Main Character of A Beautiful Mind movie Directed by Ron Howard. Wanastra: Jurnal Bahasa Dan Sastra, 10(1), 9-16. Retrieved from http://ejournal.bsi.ac.id/ejurnal/index.php/wanastr a/article/view/2648/2061

Barry, P. (2009). Beginning Theory An Introduction to Literary and Cultural Theory (2nd ed). New York: Manchester University Press.

Bethards, B. (2003). The Dream Book Symbols for Self Understanding (19th ed). United States of America: New Century Publisher.

Domhoff, G. W. (2013). Finding Meaning in Dreams: A Quantitative Approach. University of California: Springer Science Business Media LLC.

Hale, D. (2011). How To Interpret Dreams - Dreams Secrets 2. Coast \& Country.

Khairunnas, S., Pratama, R. M. D., \& Wardani, E. S. (2018). Personality Of Main Character In Jobs Film Directed By. Wanastra, 10(2), 35.

Klarer, M. (2004). AN INTRODUCTION TO LITERARY STUDIES Third edition. New York: Routledge.

Petrie, D., \& Boggs, J. (2008). The Art of Watching Films 7th Edition. New York: Mayfield Publishing company. Print.

Parse, R. (2001). Qualitative Inquiry: The Path of Sciencing. Burlington, US: Jones \& Bartlett Learning.

Robbins, R. A., \& Johansen, S. (2013). Your Client's Story: Persuasive Legal Writing. New York: Wolters Kluwe Law \& Bussiness.

Roberts \& Jacobs. (2006). An Introduction to Reading and Writing (Compact Th). New York: Prentice Hall.
Santas, C. (2002). Responding to Film: A Text Guide for Students of Cinema Art. Chicago: Burnham inc., Publishers.

Schredl, M. (2018). Researching Dreams: The Fundamental. Germany: Springer International Publishing.

Schweitzer, R. D. (2003). A Phenomenological Explication of Dream Interpretation Among Rural and Urban Nguni People. South Africa: Rhodes University.

Tejera, D. (2009). Absolutely Nothing. United States of America: Xlibris Corporation.

Yastanti, U., Suhendar, J., Mirani, R., Pratama, D., Bina, U., Informatika, S., Informatika, S. (2018). PROGRESSIVE Vol . XIII, No . 2 September 2018 ISSN : 1979-4975, XIII(2).

Yastanti, U., \& Widhiyanto, B. (2018). PROGRESSIVE Vol . XIII , No . 1 Maret 2018 PROGRESSIVE Vol . XIII, No. 1 Maret 2018. Wanastra: Jurnal Bahasa Dan Sastra, XIII(1), 23-34. 